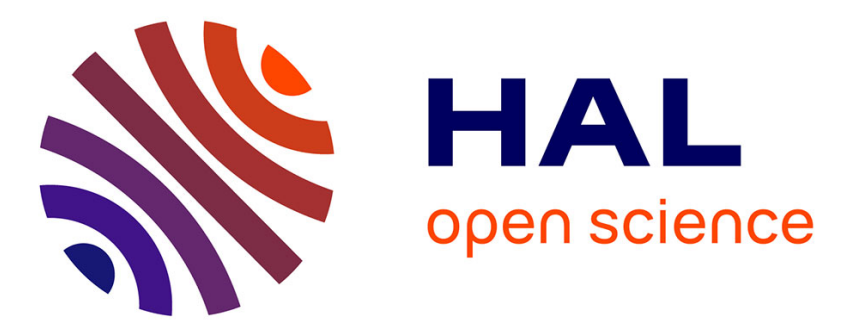

\title{
Logical Decision-Making Method Relating to Innovation Management
}

Nélio Reis, Priscila Tavares, Cristina Oliveira, Jair Minoro Abe

\section{To cite this version:}

Nélio Reis, Priscila Tavares, Cristina Oliveira, Jair Minoro Abe. Logical Decision-Making Method Relating to Innovation Management. IFIP International Conference on Advances in Production Management Systems (APMS), Sep 2016, Iguassu Falls, Brazil. pp.12-19, 10.1007/978-3-319-51133-7_2 . hal-01615717

\section{HAL Id: hal-01615717 \\ https://hal.inria.fr/hal-01615717}

Submitted on 12 Oct 2017

HAL is a multi-disciplinary open access archive for the deposit and dissemination of scientific research documents, whether they are published or not. The documents may come from teaching and research institutions in France or abroad, or from public or private research centers.
L'archive ouverte pluridisciplinaire HAL, est destinée au dépôt et à la diffusion de documents scientifiques de niveau recherche, publiés ou non, émanant des établissements d'enseignement et de recherche français ou étrangers, des laboratoires publics ou privés.

\section{(c)(1)}

Distributed under a Creative Commons Attribution| 4.0 International License 


\title{
Logical Decision-Making Method Relating to Innovation Management
}

\author{
Nélio F. dos Reis ${ }^{1,2}$, Priscila Facciolli S. L. Tavares ${ }^{1}$, Cristina Oliveira ${ }^{1}$, Jair Minoro \\ $\mathrm{Abe}^{1}$ \\ ${ }^{1}$ Paulista University, São Paulo, Brazil \\ ${ }^{2}$ Federal Institute of Education, Science and Technology of São Paulo \\ neliojundiailig.com.br; pri1979@gmail.com
}

\begin{abstract}
This paper is intended to serve as a support for decision in innovation management from the $\mathrm{E} \tau$ Logic. We intend to propose a new method for innovation management, based on technical and operational criteria in order to make decisions can be not only reliable but also operationally efficient. This research presents results that can serve to innovation managers.
\end{abstract}

Keywords: Innovation · Management · Paraconsistent Annotated Logic

\section{Introduction}

Many companies claim to be innovative, creative and be ahead of your competitors, despite the fact that they are not using appropriate metrics and methods to innovative processes and results.

The model for this purpose is built through an approach of Paraconsistent Logic Annotated Evidential $\mathrm{E} \tau(\mathrm{E} \tau$ Logic), a technique that is gaining space and consideration in the various fields of research.

The main advantages of the use of $\mathrm{E} \tau$ Logic derived from one of the input parameters are set by the thought of evaluator's structure, consolidating a collective logic translated into mathematical terms.

De Bes e Kotler [1] claim that "without innovation companies end up." Innovation is the development and introduction of a new idea, making it a process, product or service. O'Sullivan [2], states that: "Innovation is the process by which the productive resources are developed and used to generate higher quality and / or lower cost products compared to the current available". According to Tidd e Bessant [3], innovation "is more than just having good ideas is the process of growing them".

\subsection{Innovation}

Sinsit [4], he distinguishes invention of innovation as follows: "invention is the creation of a new idea or concept. While innovation transforms the new concept in commercial success or general use. Ronan [5], explains innovation as "profitable implementation

adfa, p. 1, 2011.

(C) Springer-Verlag Berlin Heidelberg 2011 
of strategic creativity and which comprises four main components (1) creativity, (2) strategy (3) implementation and (4) profit".

Innovation is both a strategic factor for companies willing to remain competitive in the long term [6] and [7], as one of the least known aspects of business as states Takeuchi e Nonaka [8]. Due to increased competition, changes in demand and customer tastes, it seems extremely important for companies to manage innovation in a fast and flexible way in order to beat the competition and achieve a sustainable competitive advantage.

The scope of the innovation can be incremental or disruption [9]: "Incremental: typically performed to improve a product or service with a new feature that is easily integrated; and radical: usually associated with disruption for new steps and unpredictable uses for existing technology." Still according to Vacek [9], the common places of innovation are product, process, structure and market.

\subsection{Innovation Models}

Many companies claim to be innovative, creative and be ahead of their competitors, despite the fact that they are not using appropriate metrics and methods to innovative processes and results. "Innovation is a disorderly process: difficult to measure and difficult to manage [1]."

However, states that innovation is an art, not a science and it is therefore not possible to predict the success of an innovation until it is accepted by the respective market [10]. Since the 1950s there has been a proliferation of innovation models, each with the purpose of guiding the innovation process within companies, as summarized in Tab 1.

Table 1. Development of innovation models (Adapted from Hobday [11])

\begin{tabular}{|l|c|l|}
\hline \multicolumn{1}{|c|}{ Model } & \multicolumn{1}{c|}{ Generation } & \multicolumn{1}{c|}{ Feature } \\
\hline Technological & $1^{\mathrm{a}}(1950-1960)$ & Emphasis on R\&D. Innovation R\&D. \\
\hline Market & $2^{\mathrm{a}}(1960-1970)$ & Market is the source of new ideas for R\&D \\
\hline Coupled & $3^{\mathrm{a}}(1970-1980)$ & Feedback link between market and R\&D. \\
\hline Interactive & $4^{\mathrm{a}}(1980-1990)$ & Emphasis in marketing and R\&D. \\
\hline Network & $5^{\mathrm{a}}(1990-2000)$ & Knowledge and systems integration. \\
\hline Open & $6^{\mathrm{a}}(2000-$ current $)$ & Combined ideas for innovation. \\
\hline
\end{tabular}

For each step, there are several tools and techniques that can be selected based on company structure, the target market or type of products or services. The decision-making method in Innovation Management is established not as a process of innovation, but through the interaction between six distinct phases: identification, intelligence, idealization, instrumentation, implementation and indicators. These phrases have been identified in the A-F models [1], who claim: "This model results from analysis of various companies that are consider innovative and have good results concerning the time and resources invested in innovation: Apple, Google, Netflix, 3M, Procter \& Gamble, 
General Electric, BMW, Frito Lay, IBM, Toyota, Southwest Airlines, Starbucks, Microsoft, Tesco, Royal Dutch / Shell, Walmart, Exxon, Ikea, Ericsson, Nokia and Corning were the main companies studied".

\subsection{E $\tau$ Logical}

The E $\tau$ logical allows to treat subjective data from the real worldinto accurate data with numerical outputs [12]. One of its advantages is to perform the translation of natural language (linguistic terms) used in daily communication in mathematical expressions. This is achieved by means of crosslinked annotation properties.

De Carvalho e Abe [13], states that: "In E $\tau$ logical logical every $\boldsymbol{p}$ prepositio associates, $\mathrm{n}$ commom sense, a pair $(\mu, \lambda)$, represented by Greek letters $m i(\mu)$ and lambda $(\lambda)$, depicted in the following manner: $\boldsymbol{p}_{(\mu ; \lambda)}$. $\boldsymbol{\mu}$ nd $\boldsymbol{\lambda}$ varies in the real closed interval [0, $1]$. Therefore, the pair $(\mu ; \lambda)$ belongs to the Cartesian product $[0,1] \times[0,1]$. Intuitively, $\mu$ represents the degree of favorable evidence expressed in $\boldsymbol{p}$, nd $\lambda$, the degree of contrary evidence expressed by $\boldsymbol{p}$. The pair $(\mu, \lambda)$ It is called annotation constant or simply note. The atomic propositions of E $\tau$ logical are $\boldsymbol{p}_{(\mu ; \lambda)}$ type".

The advantages in the development of paraconsistent systems are: how quickly the building of system is carried out in relation to models based on logic "fuzzy" (common or Boolean) and make it unnecessary knowledge or the development of a mathematical model [13]. Innovation is important, but that executives lack confidence in their decisions [1].

The decision-making method in Innovation Management is established through six distinct phases, as follows [1]: (i) Identification: Expressed by X percentage of the population on the whole; (ii) Intelligence: Translated globally in size of the impact on the innovation site; (iii) Idealization: The Y amount, of ideas attributes, can be presented as a comparison measurement with the average $M$ attributes in available similar. (iv) Instrumentation: Can be represented by the average expenditure $\mathrm{G}$ function compared to similar available $S$; (v) Implementation: In period $\mathrm{P}$ to development and implantation measured as a function of $\mathrm{C}$ lifecycle; and (vi) Indicators: Investment I measured by the $\mathrm{R}$ expected return on the life cycle of innovation.

\section{Methods}

The methodology used was as follows: 1) Problem in the form of question: - How to make innovation management with contradictory data? 2) Elaborated hypothesis: - You can take decision in innovation management with logical data. 3) Literature review: Theoretical research on innovation and E $\tau$ Logic. 4) Data collection: - Expert systems, divided into three groups: - A: 03 (three) innovation experts; - B: 03 (three) management experts; and - C: 02 (two) risk investment experts. 5) Study object: - Extensive direct observation of experts.

The experts evaluated the Six I's factors for innovation in product, process and market. Initially the experts understood the model. After that, brainstorm sessions were 
conducted to identify the factors and building the logical proposition. The Six I's and the propositions are presented in the table below.

Table 2. Six I's and Propositions

\begin{tabular}{|c|c|c|c|}
\hline Factors & Sections & Propositions & Description \\
\hline \multirow{3}{*}{$\begin{array}{l}\text { Identifica- } \\
\text { tion } \\
\text { I1 }\end{array}$} & $\mathrm{S} 1$ & $X>70 \%$ & $\begin{array}{l}\text { The population benefited } \mathrm{X} \text { is greater than } 70 \% \text { of the } \\
\text { whole. }\end{array}$ \\
\hline & $\mathrm{S} 2$ & $30 \% \leq X \leq 70 \%$ & $\begin{array}{l}\text { The population benefited } \mathrm{X} \text { is greater than or equal to } 30 \% \\
\text { and less than or equal to } 70 \% \text { of the whole. }\end{array}$ \\
\hline & $\mathrm{S} 3$ & $X<30 \%$ & The population benefited $\mathrm{X}$ is less than $30 \%$ of the whole. \\
\hline \multirow{3}{*}{$\begin{array}{l}\text { Intelligence } \\
\text { I2 }\end{array}$} & $\mathrm{S} 1$ & Large & Major positive impact at the place of innovation \\
\hline & $\mathrm{S} 2$ & Medium & Medium positive impact on the local of innovation \\
\hline & S3 & Small & Small positive impact on the local of innovation \\
\hline \multirow{3}{*}{$\begin{array}{l}\text { Idealization } \\
\qquad \text { I3 }\end{array}$} & $\mathrm{S} 1$ & $\mathrm{Y}>1,5 \mathrm{M}$ & $\begin{array}{l}\text { Y innovation attributes are } 1.5 \text { times higher than the aver- } \\
\text { age similar M. }\end{array}$ \\
\hline & $\mathrm{S} 2$ & $\begin{array}{c}0,5 \mathrm{M} \leq \mathrm{Y} \leq \\
1,5 \mathrm{M}\end{array}$ & $\begin{array}{l}\text { Y attributes of innovation are greater than or equal to } 0.5 \\
\text { times and less than or equal to } 1.5 \text { times the similar aver- } \\
\text { age. }\end{array}$ \\
\hline & $\mathrm{S} 3$ & $\mathrm{Y}<0,5 \mathrm{M}$ & $\begin{array}{l}\text { Y attributes of innovation are greater than or equal to } 0.5 \\
\text { times and less than or equal to } 1.5 \text { times the similar aver- } \\
\text { age. }\end{array}$ \\
\hline \multirow{3}{*}{$\begin{array}{l}\text { Instrumen- } \\
\text { talization } \\
\text { I4 }\end{array}$} & $\mathrm{S} 1$ & $\mathrm{G}<40 \% \mathrm{~S}$ & $\begin{array}{l}\text { Average spending } \mathrm{G} \text { innovation is less than } 40 \% \text { of similar } \\
\text { S. }\end{array}$ \\
\hline & $\mathrm{S} 2$ & $\begin{array}{c}70 \% \mathrm{~S} \leq \mathrm{G} \leq \\
40 \% \mathrm{~S}\end{array}$ & $\begin{array}{l}\text { Average spent } \mathrm{G} \text { of innovation is greater than or equal to } \\
70 \% \text { and less than or equal to } 40 \% \text { similar to } \mathrm{S} \text {. }\end{array}$ \\
\hline & $\mathrm{S} 3$ & $\mathrm{G}>70 \% \mathrm{~S}$ & $\begin{array}{l}\text { Average spent } \mathrm{G} \text { of innovation is greater than } 70 \% \text { similar } \\
\text { to } \mathrm{S} \text {. }\end{array}$ \\
\hline \multirow{3}{*}{$\begin{array}{l}\text { Implemen- } \\
\text { tation } \\
\text { I5 }\end{array}$} & $\mathrm{S} 1$ & $\mathrm{P}<30 \% \mathrm{C}$ & $\begin{array}{l}\text { P deadline of development and deployment of innovation } \\
\text { is less than } 30 \% \text { of the current life cycle. }\end{array}$ \\
\hline & $\mathrm{S} 2$ & $\begin{array}{c}30 \% \mathrm{C} \leq \mathrm{P} \leq \\
70 \% \mathrm{C}\end{array}$ & $\begin{array}{l}\text { P deadline of development and deployment of innovation } \\
\text { is greater than or equal to } 30 \% \text { and less than or equal to } \\
70 \% \text { of the current life cycle. }\end{array}$ \\
\hline & $\mathrm{S} 3$ & $\mathrm{P}>70 \% \mathrm{C}$ & $\begin{array}{l}\text { P deadline of development and deployment of innovation } \\
\text { is greater than } 70 \% \text { of the current life cycle. }\end{array}$ \\
\hline \multirow{3}{*}{$\begin{array}{l}\text { Indicators } \\
\qquad \text { I6 }\end{array}$} & $\mathrm{S} 1$ & $\mathrm{I}<30 \% \mathrm{R}$ & $\begin{array}{l}\text { Investment in innovation is less than } 30 \% \text { of the expected } \\
\text { return in the life cycle. }\end{array}$ \\
\hline & $\mathrm{S} 2$ & $\begin{array}{c}30 \% \mathrm{R} \leq \mathrm{I} \leq \\
70 \% \mathrm{R}\end{array}$ & $\begin{array}{l}\text { Investment in innovation is greater than or equal to } 30 \% \\
\text { and less than or equal to } 70 \% \text { of the expected return in the } \\
\text { life cycle. }\end{array}$ \\
\hline & $\mathrm{S} 3$ & $\mathrm{I}>70 \% \mathrm{R}$ & $\begin{array}{l}\text { Investment in innovation is greater than } 70 \% \text { of the ex- } \\
\text { pected return in the life cycle. }\end{array}$ \\
\hline
\end{tabular}


Were executed two (02) Delphi rounds that sought to: identify the certainty of the expert regarding the decision of each factor and the possible contradiction in relation to expert.

The consultation was conducted by form via email. The biggest difference between them is that in the second round, the answers to each of the first round proposals of all the experts had the result informed, giving the respondent an opportunity to review its earlier evidence, if desired.

\section{Aplication}

Regarding the factors, one should reason that they are independent of each other. Thus, the experts allocated their degree of favorable evidence $(\mu)$ and contrary evidence $(\lambda)$ in each proposition, as shown in Figure 1.

\begin{tabular}{|c|c|c|c|c|c|c|c|c|c|c|c|c|c|c|c|c|c|}
\hline \multirow{3}{*}{ 总 } & \multirow{3}{*}{ 를 } & \multicolumn{6}{|c|}{ Group A } & \multicolumn{6}{|c|}{ Group B } & \multicolumn{4}{|c|}{ Group C } \\
\hline & & \multicolumn{2}{|c|}{ Experts 1} & \multicolumn{2}{|c|}{ Experts 2} & \multicolumn{2}{|c|}{ Experts 3} & \multicolumn{2}{|c|}{ Experts 4} & \multicolumn{2}{|c|}{ Experts 5} & \multicolumn{2}{|c|}{ Experts 6} & \multicolumn{2}{|c|}{ Experts 7} & \multicolumn{2}{|c|}{ Experts 8} \\
\hline & & $\mu_{1}$ & $\lambda_{1}$ & $\boldsymbol{\mu}_{2}$ & $\lambda_{2}$ & $\mu_{3}$ & $\lambda_{3}$ & $\mu_{4}$ & $\lambda_{4}$ & $\mu_{5}$ & $\lambda_{s}$ & $\mu_{6}$ & $\lambda_{6}$ & $\boldsymbol{\mu}_{7}$ & $\lambda_{7}$ & $\mu_{s}$ & $\lambda_{s}$ \\
\hline \multirow{3}{*}{ I1 } & S1 & 1,0 & 0,1 & 0,3 & 0,2 & 0,8 & 0,3 & 0,3 & 0,2 & 0,9 & 0,3 & 0,7 & 0,1 & 0,3 & 0,2 & 0,2 & 0,0 \\
\hline & $\mathrm{S} 2$ & 0,5 & 0,5 & 0,4 & 0,6 & 0,6 & 0,4 & 0,6 & 0,4 & 0,4 & 0,6 & 0,5 & 0,5 & 0,5 & 0,5 & 0,5 & 0,5 \\
\hline & S3 & 0,1 & 1,0 & 0,2 & 0,9 & 0,3 & 0,8 & 0,3 & 0,9 & 0,3 & 0,9 & 0,1 & 0,9 & 0,3 & 1,0 & 0,0 & 1,0 \\
\hline \multirow{3}{*}{$\mathrm{I} 2$} & $\mathrm{~S} 1$ & 0,8 & 0,4 & 0,9 & 0,3 & 0,7 & 0,1 & 1,0 & 0,1 & 0,9 & 0,2 & 0,8 & 0,3 & 0,8 & 0,3 & 0,9 & 0,2 \\
\hline & $\mathrm{S} 2$ & 0,5 & 0,5 & 0,4 & 0,6 & 0,6 & 0,4 & 0,6 & 0,4 & 0,4 & 0,6 & 0,5 & 0,5 & 0,5 & 0,5 & 0,5 & 0,5 \\
\hline & S3 & 0,1 & 1,0 & 0,2 & 0,9 & 0,3 & 0,8 & 0,3 & 0,9 & 0,3 & 0,9 & 0,1 & 0,9 & 0,3 & 1,0 & 0,0 & 1,0 \\
\hline \multirow{3}{*}{ I3 } & S1 & 1,0 & 0,1 & 0,9 & 0,2 & 0,8 & 0,3 & 0,8 & 0,4 & 0,9 & 0,3 & 0,7 & 0,1 & 0,9 & 0,1 & 0,9 & 0,1 \\
\hline & $\mathrm{S} 2$ & 0,5 & 0,5 & 0,4 & 0,6 & 0,6 & 0,4 & 0,6 & 0,4 & 0,4 & 0,6 & 0,5 & 0,5 & 0,5 & 0,5 & 0,5 & 0,5 \\
\hline & S3 & 0,1 & 1,0 & 0,2 & 0,9 & 0,3 & 0,8 & 0,3 & 0,9 & 0,3 & 0,9 & 0,1 & 0,9 & 0,3 & 1,0 & 0,0 & 1,0 \\
\hline \multirow{3}{*}{ I4 } & S1 & 0,8 & 0,4 & 0,9 & 0,3 & 0,7 & 0,1 & 1,0 & 0,1 & 0,9 & 0,2 & 0,8 & 0,3 & 0,8 & 0,3 & 0,9 & 0,2 \\
\hline & $\mathrm{S} 2$ & 0,5 & 0,5 & 0,4 & 0,6 & 0,6 & 0,4 & 0,6 & 0,4 & 0,4 & 0,6 & 0,5 & 0,5 & 0,5 & 0,5 & 0,5 & 0,5 \\
\hline & S3 & 0,1 & 1,0 & 0,2 & 0,9 & 0,3 & 0,8 & 0,3 & 0,9 & 0,3 & 0,9 & 0,1 & 0,9 & 0,3 & 1,0 & 0,0 & 1,0 \\
\hline \multirow{3}{*}{ I5 } & S1 & 1,0 & 0,1 & 0,9 & 0,2 & 0,8 & 0,3 & 1,0 & 0,1 & 0,9 & 0,2 & 0,8 & 0,3 & 0,9 & 0,1 & 0,9 & 0,1 \\
\hline & $\mathrm{S} 2$ & 0,5 & 0,5 & 0,4 & 0,6 & 0,6 & 0,4 & 0,6 & 0,4 & 0,4 & 0,6 & 0,5 & 0,5 & 0,5 & 0,5 & 0,5 & 0,5 \\
\hline & S3 & 0,1 & 1,0 & 0,2 & 0,9 & 0,3 & 0,8 & 0,3 & 0,9 & 0,3 & 0,9 & 0,1 & 0,9 & 0,3 & 1,0 & 0,0 & 1,0 \\
\hline \multirow{3}{*}{ I6 } & S1 & 0,8 & 0,4 & 0,9 & 0,3 & 0,7 & 0,1 & 0,8 & 0,4 & 0,9 & 0,3 & 0,7 & 0,1 & 0,7 & 0,4 & 1,0 & 0,0 \\
\hline & $\mathrm{S} 2$ & 0,5 & 0,5 & 0,4 & 0,6 & 0,6 & 0,4 & 0,6 & 0,4 & 0,4 & 0,6 & 0,5 & 0,5 & 0,5 & 0,5 & 0,5 & 0,5 \\
\hline & S3 & 0,1 & 1,0 & 0,2 & 0,9 & 0,3 & 0,8 & 0,3 & 0,9 & 0,3 & 0,9 & 0,1 & 0,9 & 0,3 & 1,0 & 0,0 & 1,0 \\
\hline
\end{tabular}

Fig. 1. Database of evidence from experts

With the Table 1 database, it emerges clearly the evidence of experts on the Six I's factors. They are shown in Table 3 with use of Maximum and Minimum rules.

\subsection{Maximization (Max) and Minimization (Mini) rules}

The next step is to apply the maximization (Max) and minimizing (Min) rule to the evidence of the experts for each innovation factors.

Apply to the rules of maximization of favorable evidence within groups being connective (Max) the favorable evidence and connective (Min) in contrary evidence within 
each group and the minimization rule of favorable evidence among the groups, the connective ( $\min$ ) the favorable evidence, and connective (Max) in contrary evidence to the results obtained in the three groups (between groups), grouped as shown in Figure 2:

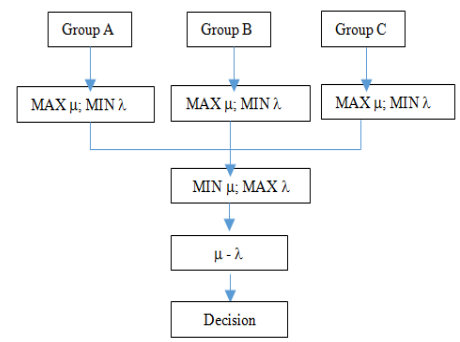

Fig. 2. Application of the scheme of MAX and MIN operators.

\subsection{Analysis}

There is favorable or contrary evidence of innovation acceptance, if there is a degree of certainty in magnitude equal to or greater than 0.6 . This level of demand may change depending on the focus of innovation. However, in this study, the value after discussions with experts are as follows.

The Certainty is defined as follows: $\mathrm{G}_{\text {cert }}=\mu-\lambda$

Summarizing, the division criterion is the following:

a) $\mathrm{G}_{\text {cert }} \geq 0,6 \rightarrow$ True (T), ie, INNOVATE;

b) $\mathrm{G}_{\text {cert }} \leq-0,6 \rightarrow$ False (F), ie, NOT INNOVATE; and

c) $-0,6<$ Gcert $<0,6 \rightarrow$ Area between Truth and False is DOUBT.

The database was treated with connective Max and Min and the results of the three themes are shown in Figure 3.

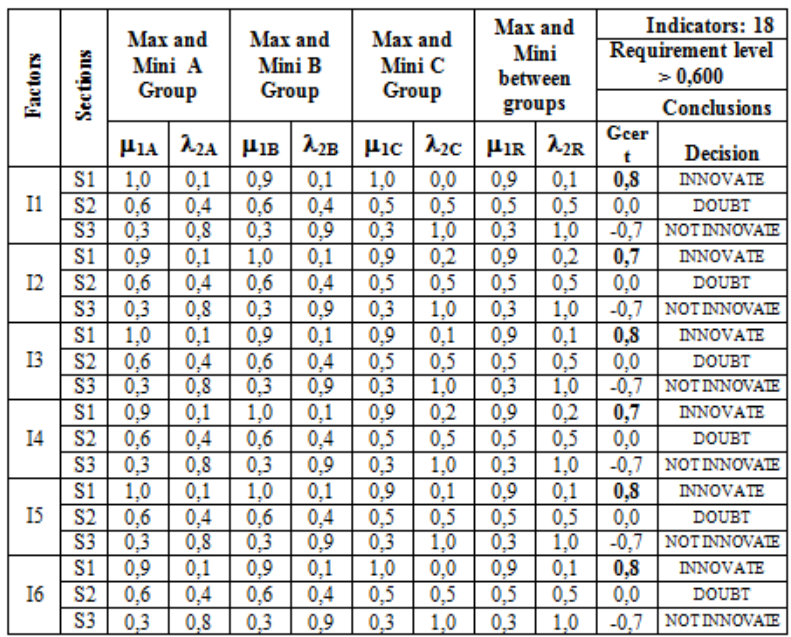

Fig. 3. Evidence degrees resulting from the application of Max and Mini rules 
Observing the degree of favorable and contrary evidence resulting from the application of maximizing rules (OR) and minimizing (AND) the evidence of experts, we note that the degree of certainty (Gcert) to $\mathrm{S} 1$ is above 0.6 as established the criteria for certainty in relation to innovation. For example, although experts E3, E4 and E7 in I1 S1 have given evidence $(\mu 0,2 ; \lambda 0,8)$ which is a statement of (F) Falsehood, so there's sure the statement is false and should not innovate, to take into account other evidence of other experts is the result (V) True, that is, this proposition is a condition for innovation. Anyway, you can tell which region he sure is. As shown in the figure is plotted on I1S1 factor $(\mu 0,9 ; \lambda 0,1)$ in the region of OPJC $=(\mathrm{V})$ true. I1S2 already has its collective evidence in the area of $(\perp)$ paracompleteza and is plotted in $(\mu 0,5 ; \lambda 0,5)$ in the central region, highlighting questions regarding innovate. I1S3 already has its collective evidence in the area of $(F)$ is plotted on falsehood $(\mu 0,3 ; \lambda 1,0)$, ie, the evidence of the expert is not innovate given this proposition. The I2S1 factor is plotted below the square unit of the Cartesian plane - QUPC, adapted from studies of De Carvalho and Abe [13]. The other results coincide with I1S1, I1S2, I1S3 and I2S1 as plotted in Figure 4.

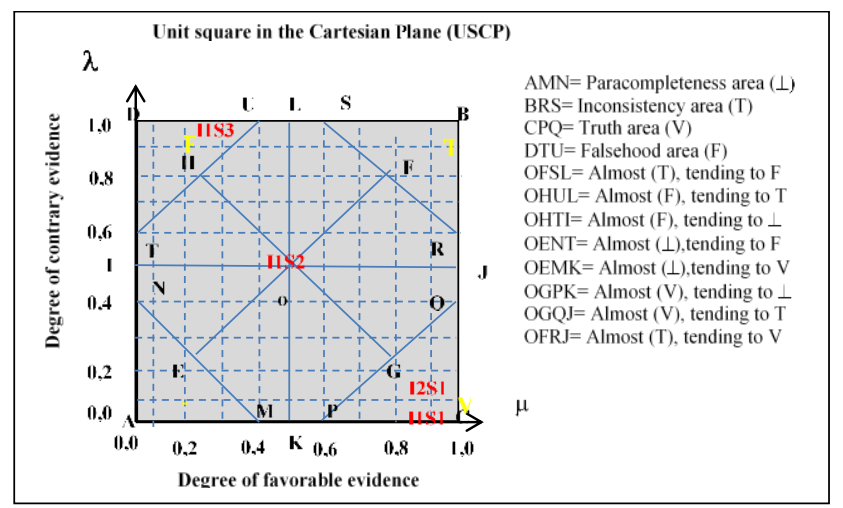

Fig. 4. Application of para-analizer device at USCP.

If there is need for a more stringent criterion for decision making, safer decision, more reliable, it is necessary to increase the level of demand, that is, one should approximate the PQ and TU lines of $\mathrm{C}$ and $\mathrm{D}$, respectively, and also may use a larger number of experts, or even consider evidence assigned depending on the weight of each expert. You can still adjust and calibrate the data of propositions for a better result in decision-making.

\section{Conclusion}

If there is need for a more stringent criterion, ie, more safe and reliable decision, it is necessary to increase the level of requirement, or use a larger number of experts, or even consider the evidence given depending on the weight of each expert. A major 
advantage of this method is its versatility. Experts can be influenced, but in general are not the same for everyone. Surely, at a time of latent conflict, the expert tends to discredit innovation more than believing and the opposite can happen in times of elation, joy, but hardly all specialists will be with the same feeling. Finally, virtually all problems in which uncertainty, ambiguity or natural language of human beings is relevant present favorable situations the application of E $\tau$ Logic.

\section{References}

1. De Bes, F.T.; Kotler, P. A.: Biblía da Inovação: Princípios Fundamentais para Levar a Cultura da Inovação Contínua às Organizaçoes. São Paulo, Leya (2011)

2. O'Sullivan M.: The Innovative Enterprise and Corporate Governance. Cambridge Journal of Economics, 24(4), 393-416 (2000)

3. Tidd, J., Bessant J.: Managing Innovation: Integrating Technological, Market and Organizational Change. Wiley Press (2009)

4. Sinsit, Z.T., Vayvay, O., Ozturk, O. An Outline of Innovation Management Process: Building a Framework for Managers to Implement Innovation. Procedia - Social and Behavioral Sciences, 150, 690 - 699 (2014)

5. Ronan, D.: A Study of Innovation Measurement and Innovation Management at Irish Medical Device SME's". National University of Ireland (2009)

6. Prahalad C.K., Hamel G.: The Core Competence of the Corporation. Harward Business Review, 68(3), 79-91 (1990)

7. Gourville J.T.: The Curse of Innovation: A Theory of Why Innovative New Products Fail in the Marketplace. Marketing Research Papers, 05-06 (2005)

8. Takeuchi H., Nonaka I.: The New Product Development Game. Harvard Business Review, 137-146 (1986)

9. Vacek, J.: Innovation Management. University Washington Bothell (2009)

10. Poots A. J., Woodcock T.: Statistical Process Control for Data Without Inherent Order. BMC Medical Informatics and Decision Making, 12(1), 86 (2012)

11. Hobday, M.: Firm-level Innovation Models, Technology Analysis \& Strategic Management, 17(2), 121-145 (2005)

12. Reis, N.F.: Método Paraconsistente de Cenários Prospectivos. Universidade Paulista (2014)

13. De Carvalho, F.R.; Abe, J.M.: Tomadas de Decisão com Ferramentas da Lógica Anotada. São Paulo, Blucher (2011) 